\title{
A Study of Organizational Change and Supply Chain Management Practices: An Empirical Analysis on SME Sector in Malaysia
}

\author{
Kong Chan Leong \\ Putra Business School \\ University Putra Malaysia \\ NorSiah Binti Jaharuddin \\ Yee Choy Leong \\ Faculty of Business and Management \\ University Putra Malaysia
}

\begin{abstract}
The reason for this analysis is to introduce the correlation between organizational change and supply chain management (SCM) practices and supply chain responsiveness (SCR), and explores its relationship with upper hand. The data assortment instrument utilized was a survey which was administrated to an absolute sample of 200 managers from SMEs part in Malaysia's. The reaction rate was $70 \%$ while $60 \%$ was usable questionnaires. Sample determination depended on convenience sampling. The researches included statistical descriptive strategies, for instance theliability and validity tests and various regressions. The outcomes demonstrated that SCM practices are identified with SCR. The outcome likewise recommended that SCR is identified with upper hand take part.
\end{abstract}

Keywords: Organizational change; supply chain, SME Malaysia

\section{Introduction}

In the present serious business, there is an expanded spotlight on delivering an incentive to the customer. The emphasis on consideration of the greater part of organizations is giving products and services that are increasingly significant contrasted with its rivals. Simultaneous to the attention on customer esteem, the commercial center where organizations work today is generally perceived as being intricate and fierce (Christopher, 2000; Goldman et al., 1995). The development of supply tie plans to improve productivity, customer reaction and capacity to convey an incentive to the customers and furthermore to improve the intercorrelation and organization among firms. Because of market growing from household market to worldwide market increment customer demands, at occurrence demanding lower costs, quicker delivery, more excellent products or services and increment the assortment of things (Braunscheidel, 2005). As per Towil and Christopher, (referred to in Thatte, 2007), the end customer in the commercial center today controlled by the achievement of failure of supply chains management practices.

They expressed that getting the correct product, at the correct cost, at the ideal opportunity to the customer isn't just improved serious achievement yet additionally the way to endurance. Numerous past literatures investigated the significance of incorporating suppliers, makers, and customers or supply chain joining (Frohlich and Westbrook, 2001; Clinton and Closs, 1997) (for instance organizational change and supply chain management) in order to acquire adaptability and speed. By tending to organizational change and supply chain management practices that add to supply chain responsiveness, will enable the specialist to all the more likely comprehend the extension and exercises identified with organizational change and supply chain management that make improved degree of supply chain responsiveness in serious business commercial center.

The reason for this analysis to discover the impact of organizational change and supply chain management practices, for instance, strategic supplier organization, customer relationship, data sharing and supply chain responsiveness. This analysis likewise researches the impact of supply chain responsiveness in term of activity framework responsiveness, calculated procedure responsiveness, supplier organize responsiveness and upper hand of the firm. The paper is composed as follows. Significant literature is investigated and orchestrated first to build up a calculated model, trailed by research approach. The outcomes are then introduced alongside conversation. End and suggestion are examined at long last. 


\section{Literature Review and Hypotheses}

The analysis targets in this analysis were intended to explore the impact of organizational change and supply chain management practices as far as strategic supplier organization, customer relationship, and data sharing on supply anchor responsiveness and to decide if supply chain responsiveness has sway on upper hand of the firm. Inside these objectives, there are three ideas that should have been investigated, to acquire a comprehension of these targets. These ideas are inspected both supplier and customer (remotely) and inside. These ideas are (1) organizational change and supply chain management practices that incorporate supplier organization, customer relationship and data sharing, (2) supply chain responsiveness that incorporates activity framework responsiveness, strategic procedure responsiveness, and supplier arrange responsiveness, (3) upper hand of the firm. Organizational change and supply chain management practices as a multi-dimensional build that incorporates upstream and downstream sides of supply chain (Li et al, 2006). Donlon (1996) expressed that re-appropriating, supplier organization, data sharing, process duration, pressure and consistent procedure stream, as a piece of organizational change and supply chain management practices. While Tan et al (1998) spoke to organizational change and supply chain management practices in type of value, buying, and customer relationship.

Alvarado and Kotzab, in their experimental analysis concentrated on organizational change and supply chain management practices on between organizational framework utilized, center capabilities, and end of overabundance in stock through delay. The strategic part of organizational change and supply affix management works on as indicated by Tan et al (2002) were supply chain joining, data sharing, customer care management, geographic vicinity, and JIT abilities. Lee (2004) concentrated on five practices at supply chain level that are a strategic to make supply chain responsiveness. They incorporate re-appropriating, strategic supplier organizations, customer relationship, data sharing, and product measured quality. Chen and Paulraj (2004) likewise lead the analysis in regards to organizational change and supply chain management practices, they researched long haul relationship, cross-practical groups, supplier base decrease, and supplier inclusion.

The equivalent with Chen and Paulraj, Min and Mentzer (2004) additionally inspected in their analysis long haul relationship, data sharing, participation process reconciliation and supply chain initiative fundamental the organizational change and supply chain management practices. Untruth et al (2005,2006); Thatte (2007) recognized organizational change and supply chain management practices in type of vital supplier organization, customer relationship, and data sharing. This analysis embraces the equivalent organizational change and supply chain management practices (supplier organization, customer relationship and data sharing). In any case, this analysis directed in Malaysia point of view, particularly in customer merchandise industry. Li et al (2005); Thatte (2007) have built up a legitimate and dependable instrument to quantify organizational change and supply chain management practices. The comparative instrument likewise received in this exploration.

The literature additionally delineates organizational change and supply chain management practices from alternate points of view with objective of improving upper hand of firm. By improving upper hand of the firm, organization could improve its exhibition. Three components of organizational change and supply tie management practices lead to supply chain responsiveness. These are strategic supplier organization, customer relationship, and data sharing likewise recognized. A supply chain is a system of SME organizations in Malaysia to play out an assortment of procedures and exercises to create an incentive as products and services to end customers. (Christopher, 1992). SCM includes an incorporated and procedure situated way to deal with the management, structure and control of the supply chain, with the point of delivering an incentive for the end purchaser, by both customer assistance and diminish cost (Bowersox and Closs, 1996; Giannoccaro and Pontrandolfo, 2002). The organizational change and supply chain management has double reason, in one side is to improve the presentation of an individual organization just as that of the whole supply chain. In opposite side the organizational change and supply chain management diminishes organization total cost ( $\mathrm{Li}$ et al, 2006).

Organizational change and supply chain management (SCM) is the order which is moderately new and absence of hypothetical calculated system of built up or acknowledged technique when all is said in done. Lambert, et al., (1998) saw that "the term of SCM was initially presented by experts in the mid-1980s. Since the mid-1990s, researchers have endeavored to offer structure to the improvement of SCM. Despite the fact that the short story of this field, however the SCM literature has developed quickly (Larson and Rogers, 1998). 
Shapiro (2001) demonstrated that the SCM joining ideas from various teaches, for instance, vital management and hypothesis of the arrangement of the organization; coordination, creation and stock management; accounting management; logical determining and showcasing, and activities research. Organizational change and supply chain management (SCM) is one of business procedure progressively being utilized in the business world today and has become the focal point of scholarly consideration as of late (Ballou, Gilbert and Mukherjee, 2000). Since the idea of SCM is still being developed, there are a few hypothetical systems and analysis procedures should be created in the analysis of SCM (Tage, 1999).

In any case, numerous articles have been distributed in different orders to attempt to characterize the SCM and examine future headings and the comparing experimental analysis strategy (Cooper, et al., 1997; Lambert and Cooper, 2000; Larson and Rogers, 1998; Tage, 1999). As per Lummus and Vokurka (1999) SCM as all exercises associated with delivering products from crude material to customer, including sources of crude material and parts, manufacturing and get together, warehousing and stock following, demand section and demand management, dissemination over all channels, delivery to customers and data frameworks required to screen all action. Bowersox and Closs (1996) demonstrated that to be completely viable in current's serious business, organizations must build up their coordinated conduct to joined customers and suppliers. This extension of coordinated practices, through outer incorporation, alluded to by Bowersox and Closs (1996) as organizational change and supply chain management. The way of thinking of organizational change and supply chain management transforms into the usage of SCM: a lot of exercises that completes the way of thinking. The arrangement of exercises is facilitated exertion called organizational change and supply chain management between the supply chain accomplices, for instance, suppliers, produces and customers (Greene, 1991).

Thatte (2007) expressed that strategic supplier organization as the drawn-out correlation between the organization and its supplier. Gunasekaran et al (2001) attested that a strategic organization underscores long haul correlation between exchanging accomplices and advance shared arranging a critical thinking endeavor. Strategic organization between SME organizations in Malaysia advance shared advantages and progressing coordinated effort in strategic regions like innovation, products, and market (Yoshino and Rangan, 1995; Thatte, 2007). Vital organizations with suppliers lead organization working intently and successfully with a couple of suppliers instead of numerous supplier that have been chosen based on cost effective. Many bit of leeway of comprising supplier right off the bat in the product configuration process are that suppliers can offer financially savvy structure elective, help with choosing better parts and innovations, and help in planning appraisal (Tan et al, 2002; Thatte, 2007). In organizational change and supply chain management techniques, supplier relationship exercises assume a significant job (Wisner, 2003).

Long haul correlations allude to expectation that the game plan won't be brief (Chen and Paulraj, 2004). Through cozy relationship supply anchor accomplices are eager to share dangers and reward, and keep up the relationship on long haul premise (Landeros and Monczka, 1989; Cooper and Ellram, 1993; Stuart, 1993; Thatte, 2007). Toni and Nassimbeni (1999) distinguished that a drawn-out viewpoint between the purchaser and supplier increment the power of firm-supplier mix. Firms that coordinate with customers including: arranging, executing, and assessing an effective correlation between the supplier and beneficiary of both upstream and downstream of the supply chain. In this way, customer relationship management (CRM) isn't just centered around inbound customer correlations yet additionally on outbound customer correlations in SCM. Customer relations identified with the organization's capacity to convey to the delivery of suitable products and services to customers locally and internationally in the ideal time, correct spot, and proper of amount and quality. Customer linkage particularly imparting product data to customers, accepting customer orders, cooperate with customers to oversee demand, in the wake of submitting the demand framework, share the status of demands with customers on planning demands, and product delivery stage (Lee, et al, 2007). An organization's customer relationship practices can create the organizational accomplishment in organizational change and supply chain management practices endeavors just as its presentation (Scott and Westbrook, 1991; Ellram, 1991; Turner, 1993).

The achievement of organizational change and supply chain management includes customer combination at the downstream and supplier joining at the upstream, taking into account that every substance in a supply chain is a supplier just as a customer (Tan et al., 1999; Thatte, 2007). In the serious business, better relationship management with customers is significant for organization achievement (Wines, 1996). Great correlation with colleagues, including strategic customers is significant job to achievement of organizational change and supply chain management practiced by organization (Moberg et al, 2002; Tathee, 2007). Customer relationship perceived as an interior part of an organization's market procedure to build deals and benefits (Bommer et, 2001; Thatte, 2007). Close customer relationship permits product separation from contenders, help continue consumer loyalty and reliability, and raised the worth give to customer (Margaretta, 198; Thatte, 2007). 
Simatupang and Sridharan, (2002) characterized data sharing as the entrance to private data between colleagues consequently empowering them to screen the advancement of products and demands as they go through different procedures in the supply chain. They recognized some of component that contain data sharing, comprising data obtaining, handling, stockpiling, introduction, recovery, and broadcasting of interest and conjecture data, stock status and area, demand status, cost-related data, and performance status. They additionally add that data sharing relating to strategic performance metric and procedure data improves the supply chain perceivability accordingly empowering compelling dynamic. Data partook in a supply chain is useful just on the off chance that it is applicable, precise, opportune, and solid (Simatupang and Sridharan, 2005; Tathee, 2007). Data imparting to colleagues empowers SME organizations in Malaysia settling on better choices and making activity based on more noteworthy perceivability (Davenport, et al, 2001; Tathee, 2007). Lumnus and Vokurka (1999, refered to in Thatte, 2007) expressed that so as to make the supply chain serious, a vital initial step is to gain an away from of supply chain ideas and be happy to straightforwardly impart data to supply chain accomplices. In business serious world these days, business organization ought to build up their supply bind so as to get customer reactions.

As per Thatte, (2007) the sub-builds for supply chain responsiveness incorporates activity framework responsiveness, strategic procedure responsiveness and supplier organize responsiveness. Activity framework responsiveness is the capacity of company's manufacturing framework to address changes in customer demand. It incorporates both manufacturing and management activity. Duclos et al (2003); Lumnus et al (2003) underline that responsiveness at each organization of the chain is a necessary part of supply chain responsiveness. Strategic procedure responsiveness is the capacity of organization's outbound change, dispersion and warehousing framework to address changes in customer demand. Fawcett (1992) expressed that the responsive in calculated procedure is an essential segment in the supply of a responsive supply chain system. Coordination and dissemination management includes the change exercises of products from suppliers to maker to circulation focuses to conclusive purpose of end customers (Ricker and Kalakota, 1999; Duclos et al, 2003; Thatte, 2007).

These exercises incorporate warehousing, bundling and delivery, transportation arranging and management, management stock, hold coordination and demand following and delivery. Supplier organize responsiveness is the capacity of the company's significant suppliers to address changes in the company's interest. A strategic to responsiveness is the nearness of responsive and adaptability accomplices upstream and downstream of the firm (Christopher and Peck, 2004). The capacity of the organizations to respond rapidly to customer demand is relying upon the response time of suppliers to make volume of changes. In the evolving scene, upper hand rises up out of the production of supplier skills to make customer esteem and accomplish cost and additionally separation favorable circumstances, bringing about piece of the overall industry and firm gainfulness (Barney, 1991; Coyne, 1986; Day and Wensley, 1988; Prahalad and Hamel, 1990, Thatte, 2007).

To acquire upper hand, firms need to set up hindrances that make impersonation troublesome through ceaseless speculation to improve the firm favorable position, making this a since quite a while ago run repetitive procedure (Day and Wensley, 1988; Thatte, 2007). Souza and William (2000) proposed that cost and quality is a piece of upper hand measurement. Wheelwright (1978) and Thatte (2007) additionally recommended cost, quality, steadfastness and speed of delivery as a portion of the basic serious needs for manufacturing. (Vokurka et al., 2002; Fawcett and Smith, 1995; White, 1996; Skinner, 1985; Roth and Miller, 1990; Tracey et al., 1999, Thatte, 2007) portrayed the upper hand measurements included value/cost, quality, delivery trustworthiness, and time to showcase. (viz: Stalk, 1988; Vesey, 1991; Handfield and Pannesi; 1995, Kessler and Chakrabarti, 1996; Zhang, 2001). Koufteros et al. (1997); depict the accompanying five elements of serious capacities: serious evaluating, premium estimating, value to customer quality, trustworthy delivery, and product advancement. Thatte (2007) recommended that component of upper hand: value, quality, delivery reliability, time to market, and product development. These measurements, creator utilized in this analysis. 
Based on the above literature review, the following research framework can be drawn

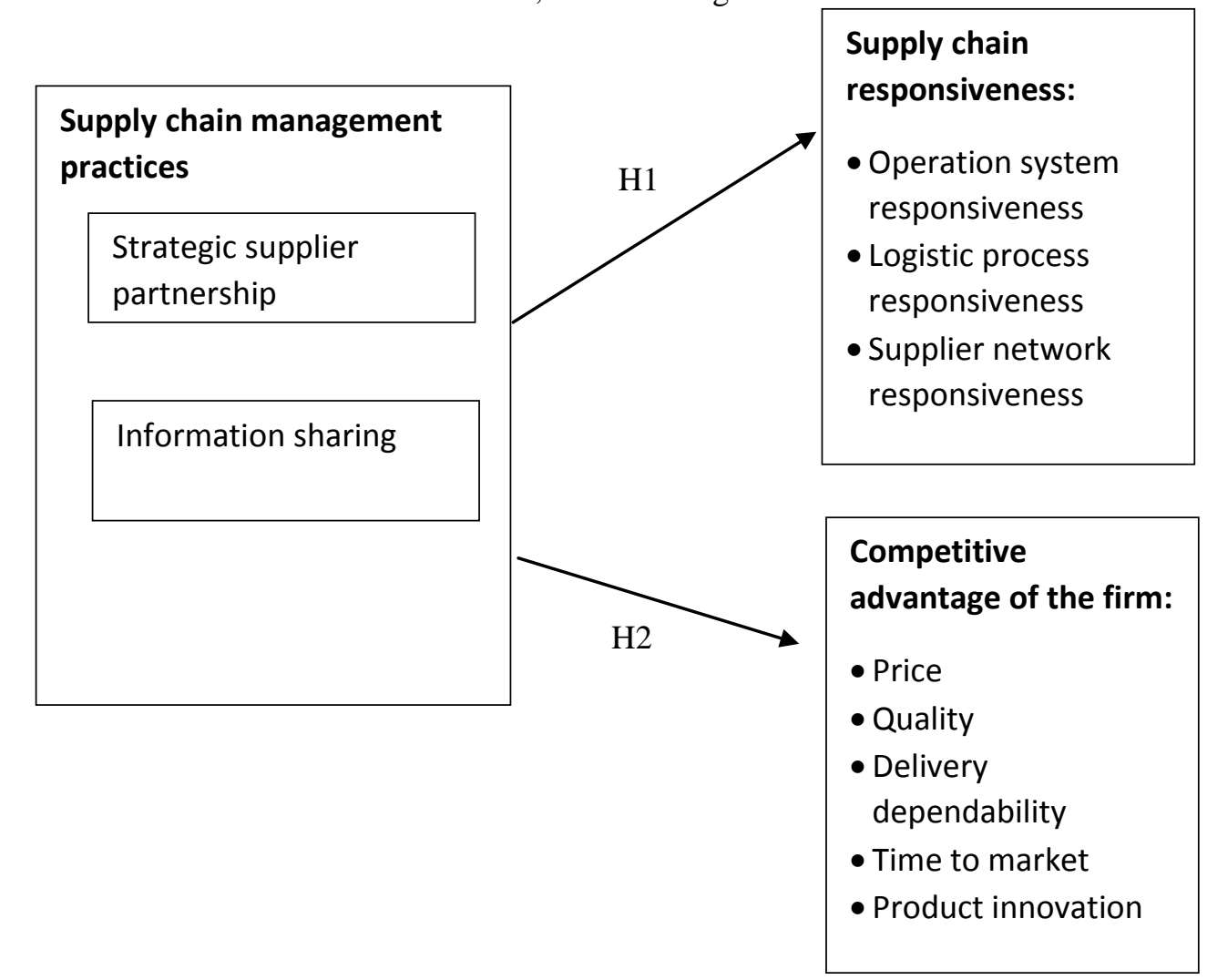

FIGURE 1: The Proposed Research Framework

This analysis looks at the organizational change and supply chain management practices that comprise of strategic supplier organization, customer relationship and data sharing and its relationship to supply chain responsiveness. Thus, the accompanying speculations will be tried: $\mathrm{H} 1$ : Organizational change and supply chain management practices are emphatically identified with supply chain responsiveness H1a : Strategic supplier organization is decidedly identified with supply chain responsiveness $\mathrm{H} 1 \mathrm{~b}$ : Customer relationship is emphatically identified with supply chain responsiveness H1c : Data sharing is emphatically identified with supply chain responsiveness We recommended that organizational change and supply chain management practices that comprise of vital supplier organization, customer relationship and data sharing and its relationship to upper hand of the firm. Thus, the accompanying hypotheses will be tried: H2: Organizational change and supply chain management practices are decidedly identified with upper hand H2a: Strategic supplier organization is emphatically identified with upper hand H2b: Customer relationship is decidedly identified with upper hand H2c: Data sharing is decidedly identified with upper hand

\section{Research Methodology}

The data assortment instrument utilized was a questionnaire which was administrated to a total sample of 200 managers from SMEs segment in Malaysia's are ordered by work title and respondents are additionally arranged by their activity capacities are corporate official, buying, fabricating/creation, appropriation/calculated, SCM, transportation, material, and activity from customer products firms in SME part in Malaysia regions.

\section{Results}

\section{Reliability Analysis:}

The Cronbach's alpha was led to survey the dependability of each scale. Alpha qualities over 0.7 show that all scales can be viewed as dependable (Nunally, 1978). For every one of the thing scales, factor analysis was utilized to decrease the absolute number of things to reasonable factor. Head parts analysis is utilized to extricate factors with eigenvalue more noteworthy than 1 . Varimax revolution is utilized to encourage understanding of the factor lattice. Sampling ampleness estimation tests are additionally analyzed by means of the Kaiser-Meyer-Olkin measurements to approve utilization of factor analysis. Table 1 shows the outcomes from factors analysis. The KMO estimation of 0.842 
demonstrates examining sufficiency. The factor model shows three unmistakable variables stacking with no misclassification: strategic supplier relationship, customer relationship and data sharing. Cronbach's alphas among 18 things in the questionnaires surpassed 0.7. Six things are distinguished for vital supplier organization (SSP), five things are recognized for customer relationship (CR), and seven things for data sharing (IS) separately. These things are treated as independent factors.

Table 1: Summary for factor analysis of SSP, CR, and IS

\begin{tabular}{|c|c|c|c|}
\hline & SSP & $\mathrm{CR}$ & IS \\
\hline We consider quality as our number one criterion in selecting suppliers & 0.52 & & \\
\hline We regularly solve problems jointly with our suppliers & 0.43 & & \\
\hline We have helped our suppliers to improve their product quality & 0.74 & & \\
\hline We have continuous improvement programs that include our key suppliers & 0.45 & & \\
\hline We include our key suppliers in our planning and goal- setting activities & 0.73 & & \\
\hline We actively involve our key suppliers in new product development processes & 0.52 & & \\
\hline We frequently interact with customers to set reliability responsiveness, and other standards for us & & 0.576 & \\
\hline We frequently measure and evaluate customer satisfaction & & 0.647 & \\
\hline We frequently determine future customer expectations & & 0.570 & \\
\hline We facilitate customers' ability to seek assistance from us & & 0.525 & \\
\hline Evaluate the importance of our relationship with our customers & & 0.701 & \\
\hline We inform trading partners in advance of changing needs & & & 0.741 \\
\hline Our trading partners share proprietary information with us & & & 0.709 \\
\hline Keep us fully informed about issues that affect our business & & & 0.712 \\
\hline Share business knowledge of core business processes with us & & & 0.653 \\
\hline Share business knowledge of core business processes with us & & & 0.735 \\
\hline Exchange information that helps establishment of business planning & & & 0.586 \\
\hline Informed about events or changes that may affect the other partner & & & 0.345 \\
\hline Cronbach's alpha & 0.76 & 0.73 & 0.85 \\
\hline KMO (Kaiser-Meyer-Olkin) value & & 0.842 & \\
\hline
\end{tabular}

Table 2: Summary for factor analysis of OSR, LOR, SNR and CA

\begin{tabular}{|c|c|c|c|c|}
\hline Items & OSR & LPR & SNR & $\mathrm{CA}$ \\
\hline Responds rapidly to changes in product volume demanded by customers & 0.562 & & & \\
\hline Responds rapidly to changes in product mix demanded by customers & 0.653 & & & \\
\hline Effectively expedites emergency customer orders & 0.644 & & & \\
\hline Rapidly reconfigures equipment to address demand changes & 0.754 & & & \\
\hline Rapidly changes manufacturing processes to address demand changes & 0.755 & & & \\
\hline Rapidly adjusts capacity to address demand changes & 0.620 & & & \\
\hline Responds rapidly to unexpected demand change & & 0.456 & & \\
\hline Rapidly adjusts warehouse capacity to address demand changes & & 0.654 & & \\
\hline Rapidly varies transportation carriers to address demand changes & & 0.543 & & \\
\hline Rapidly accommodates special or non-routine customer requests & & 0.654 & & \\
\hline Effectively delivers expedited shipments & & 0.655 & & \\
\hline Major suppliers change product volume in a relatively short time & & & 0.540 & \\
\hline Major suppliers change product mix in a relatively short time & & & 0.432 & \\
\hline Major suppliers consistently accommodate our requests & & & 0.654 & \\
\hline Major suppliers have outstanding on-time delivery record with us & & & 0.734 & \\
\hline Major suppliers effectively expedite our emergency orders & & & 0.765 & \\
\hline Major suppliers provide quick inbound logistics to us & & & 0.541 & \\
\hline We offer competitive prices & & & & 0.454 \\
\hline Offer prices as low or lower than our competitors & & & & 0.543 \\
\hline Compete based on quality & & & & 0.544 \\
\hline Offer products that are highly reliable & & & & 0.654 \\
\hline Offer products that are very durable & & & & 0.456 \\
\hline Offer high quality products to our customers & & & & 0.454 \\
\hline Deliver customer orders on time & & & & 0.655 \\
\hline Provide dependable delivery & & & & 0.765 \\
\hline Provide customized products & & & & 0.567 \\
\hline Alter our product offerings to meet client needs & & & & 0.456 \\
\hline Cater to customer needs for "new" features & & & & 0.654 \\
\hline We are first in the market in introducing new products & & & & 0.562 \\
\hline We have time-to-market lower than industry average & & & & 0.652 \\
\hline We have fast product development & & & & 0.465 \\
\hline Cronbach's alpha & 0.84 & 0.82 & 0.85 & 0.86 \\
\hline KMO (Kaiser-Meyer-Olkin) value & \multicolumn{4}{|c|}{0.777} \\
\hline
\end{tabular}


A comparative factor analysis was applied to the activity framework responsiveness (OSR), strategic procedure responsiveness (LPR), supplier arrange responsiveness (SNR) and upper hand of the firm (CA). Among 40 things in the survey, nine things are erased during the factor analysis.

A sum of 31 things were decreased to four basic variables loadings, portrayed in Table 2. Cronbach's alphas among 31 things in the surveys are surpassed 0.7. Six things are distinguished for activity framework responsiveness (OSR), five things for calculated procedure responsiveness LPR), six things for supplier organize responsiveness (SNR), and fourteen things for upper hand of the firm (CA), separately. These things are treated as dependent variables. The KMO estimation of 0.784 show sampling sufficiency.

\section{Correlation Analysis:}

Table 3 shows the correlation between independent factors (supplier strategic organization, customer relationship, and data sharing) and ward factors (supply chain responsiveness and upper hand of the firm) were certain. Strategic supplier organization had a correlation of $0.353, \mathrm{p}<0.01$ with activity framework responsiveness, $0.437, \mathrm{p}<0.01$ calculated procedure responsiveness, $0.422, \mathrm{p}<0.01$ upper hand. Which imply that the respondents are bound to assess strategic supplier organization was sure when supply chain responsiveness and upper hand are sure. Customer relationship had a correlation of 0.242 .

Table 3: The correlation between independent and dependent variables

\begin{tabular}{|c|c|c|c|c|c|c|c|c|}
\hline & & 1 & 2 & 3 & 4 & 5 & 6 & 7 \\
\hline \multirow{3}{*}{$\begin{array}{l}\text { Strategic } \\
\text { supplier } \\
\text { partnership }\end{array}$} & Pearson Correlation & 1.000 & & & & & & \\
\hline & Sig. (2-tailed) & & & & & & & \\
\hline & $\mathrm{N}$ & 200 & & & & & & \\
\hline \multirow{3}{*}{$\begin{array}{l}\text { Customer } \\
\text { relationship }\end{array}$} & Pearson Correlation & $0.398^{*+*}$ & 1.000 & & & & & \\
\hline & Sig. (2-tailed) & 0.002 & 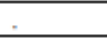 & & & & & \\
\hline & $\mathrm{N}$ & 200 & 200 & & & & & \\
\hline \multirow{3}{*}{$\begin{array}{l}\text { Information } \\
\text { sharing }\end{array}$} & Pearson Correlation & $0.506^{+*}$ & $0.302^{\text {** }}$ & 1.000 & & & & \\
\hline & Sig. (2-tailed) & 0.000 & 0.001 & & & & & \\
\hline & $\mathrm{N}$ & 200 & 200 & 200 & & & & \\
\hline \multirow{3}{*}{$\begin{array}{l}\text { Operation } \\
\text { system } \\
\text { responsiveness }\end{array}$} & Pearson Correlation & $0.353^{* *}$ & $0.242^{*}$ & $0.394^{* *}$ & 1.000 & & & \\
\hline & Sig. (2-tailed) & 0.000 & 0.026 & 0.000 & . & & & \\
\hline & $\mathrm{N}$ & 200 & 200 & 200 & 200 & & & \\
\hline \multirow{3}{*}{$\begin{array}{l}\text { Logistic process } \\
\text { responsiveness }\end{array}$} & Pearson Correlation & $0.437^{* *}$ & $0.337^{*}$ & $0.466^{* *}$ & $0.689^{* *}$ & 1.000 & & \\
\hline & Sig. (2-tailed) & 0.000 & 0.031 & 0.000 & 0.000 & 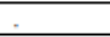 & & \\
\hline & $\mathrm{N}$ & 200 & 200 & 200 & 200 & 200 & & \\
\hline \multirow{3}{*}{$\begin{array}{l}\text { Supplier } \\
\text { network } \\
\text { responsiveness }\end{array}$} & Pearson Correlation & $0.422^{* *}$ & $0.425^{*}$ & $0.420^{* *}$ & $0.528^{* *}$ & $0.665^{* *}$ & 1.000 & \\
\hline & Sig. (2-tailed) & 0.000 & 0.049 & 0.000 & 0.000 & 0.000 & 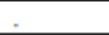 & \\
\hline & $\mathrm{N}$ & 20 & 200 & 200 & 200 & 200 & 200 & \\
\hline \multirow{3}{*}{$\begin{array}{l}\text { Competitive } \\
\text { advantage }\end{array}$} & Pearson Correlation & $0.441^{* *}$ & $0.423^{* *}$ & $0.392^{* *}$ & $0.667^{* *}$ & $0.659^{* *}$ & $0.531^{\text {** }}$ & 1.000 \\
\hline & Sig. (2-tailed) & 0.000 & 0.000 & 0.049 & 0.000 & 0.000 & 0.000 & \\
\hline & $\mathrm{N}$ & 200 & 200 & 200 & 200 & 200 & 200 & 200 \\
\hline
\end{tabular}

${ }^{*}$ p value $<0.05,{ }^{* *}$ p value $<0.01$

\section{Regression Analysis:}

The boundaries of this model are evaluated utilizing multivariate regression analysis. Table 4 shows the regression between every single independent factor (strategic supplier organization, customer relationship, and data sharing) to look at the relationship to activity framework responsiveness (OSR), strategic procedure responsiveness (LPR) and supplier arrange responsiveness (SNR). Table 4 additionally shows coefficients of each model alongside relating test measurements. In Model 1 where the dependent variable is generally speaking supply chain responsiveness (SCR), the model appears to be dependable (p-esteem for $\mathrm{F}<<0.01$ and balanced R-square of 0.320. Model 2, subordinate variable is activity framework responsiveness (OSR). The model appears to be solid (p-esteem for $\mathrm{F}<0.01$. data sharing is the most significant determinant in activity framework responsiveness with p-esteem for $\mathrm{t}<0.01$, trailed by strategic supplier organization with p-estimation of $\mathrm{t}<0.05$, while customer relationship is noteworthy with $\mathrm{p}$-estimation of $\mathrm{t}<0.05$. Model 3, subordinate variable is strategic procedure responsiveness (LPR). 
Table 4: Model parameter estimates of supply chain responsiveness (t- Value in parenthesis)

\begin{tabular}{|c|c|c|c|c|}
\hline & $\begin{array}{l}\text { Model 1 } \\
\text { Dependent variable }= \\
\text { overall SCR }\end{array}$ & $\begin{array}{l}\text { Model 2 } \\
\text { Dependent variable }= \\
\text { OSR }\end{array}$ & $\begin{array}{l}\text { Model 3 } \\
\text { Dependent } \\
\text { variable = LPR }\end{array}$ & $\begin{array}{l}\text { Model 4 } \\
\text { Dependent variable } \\
=\text { SNR }\end{array}$ \\
\hline Constant & $\begin{array}{c}116.211 \\
(7.422)^{* *}\end{array}$ & $\begin{array}{c}22.099 \\
(7.095)^{* *}\end{array}$ & $\begin{array}{c}16.214 \\
(5.812)^{* *}\end{array}$ & $\begin{array}{c}18.194 \\
(6.481)^{* *}\end{array}$ \\
\hline Strategic supplier partnership & 0.949 & 0.206 & 0.172 \\
$(2.101)^{*}$ & 0.180 \\
& $(2.066)^{*}$ & $(2.257)^{*}$ & $0.185)^{*}$ \\
\hline Customer relationship & 1.021 & 0.109 & 0.110 \\
& $(1.989)^{*}$ & $(1.072)^{*}$ & $0.172)^{*}$ & $(1.193)^{*}$ \\
\hline Information Sharing & 1.524 & 0.277 & $(2.901)^{* *}$ & 0.163 \\
& $(3.513)^{* *}$ & $0.208)^{* *}$ & 0.285 & 0.163 \\
\hline Adj R2 & 0.320 & $10.000^{* *}$ & $8.643^{* *}$ & $6.529^{* *}$ \\
\hline F-value & $12.253^{* *}$ & & &
\end{tabular}

${ }^{*}$ p value $<0.05,{ }^{* *}$ p value $<0.01$

Table 5 shows the regression of organizational change and supply chain management practices in term of strategic supplier organization, customer relationship and data sharing and its relationship with upper hand in term of value, quality, delivery trustworthiness, time to market, and product development. In Model 5 where the dependent variable is generally speaking upper hand (CA), the model is by all accounts dependable (pvalue for $\mathrm{F}<0.01$ and balanced Rsquare of 0.422. data sharing is the most significant determinant in general upper hand with $\mathrm{p}$-esteem for $\mathrm{t}<0.05$. Model 6 , subordinate variable is value $(\mathrm{P})$. The model appears to be dependable ( $\mathrm{p}$-esteem for $\mathrm{F}<0.05$. Model 7 , subordinate variable is quality $(\mathrm{Q})$. The model likewise appears to be solid (p-esteem for $\mathrm{F}<0.05$ ).

Model 8, subordinate variable is delivery steadfastness (DD). The model additionally appears to be dependable (pesteem for $\mathrm{F}<0.01$ ).

Table 5: Model parameter estimates of competitive advantage (t- Value in parenthesis)

\begin{tabular}{|c|c|c|c|c|c|c|}
\hline & $\begin{array}{l}\text { Model } 5 \\
\text { Dependent } \\
\text { variable = } \\
\text { overall CA }\end{array}$ & $\begin{array}{l}\text { Model } 6 \\
\text { Dependent } \\
\text { variable = } \\
\text { Price }(\mathrm{P})\end{array}$ & $\begin{array}{l}\text { Model } 7 \\
\text { Dependent } \\
\text { variable = } \\
\text { Quality }(Q)\end{array}$ & $\begin{array}{l}\text { Model } 8 \\
\text { Dependent variable } \\
=\text { Delivery } \\
\text { dependability (DD) }\end{array}$ & $\begin{array}{l}\text { Model } 9 \\
\text { Dependent } \\
\text { variable = Time } \\
\text { to Market (TM) }\end{array}$ & $\begin{array}{l}\text { Model } 10 \\
\text { Dependent } \\
\text { variable = Product } \\
\text { innovation (PI) }\end{array}$ \\
\hline Constant & $\begin{array}{c}126.311 \\
(8.522)^{* * *}\end{array}$ & $\begin{array}{c}25.079 \\
(8.094)^{* *}\end{array}$ & $\begin{array}{c}17.314 \\
(6.712)^{* *}\end{array}$ & $\begin{array}{c}18.293 \\
(6.571)^{* *}\end{array}$ & $\begin{array}{c}20.195 \\
(7.279)^{* *}\end{array}$ & $\begin{array}{c}19.184 \\
(7.582)^{* *}\end{array}$ \\
\hline $\begin{array}{c}\text { Strategic supplier } \\
\text { partnership }\end{array}$ & $\begin{array}{c}0.847 \\
(2.056)^{*} \\
\end{array}$ & $\begin{array}{c}0.102 \\
(2.356)^{*} \\
\end{array}$ & $\begin{array}{c}0.152 \\
(2.521)^{*} \\
\end{array}$ & $\begin{array}{c}0.187 \\
(2.984)^{*} \\
\end{array}$ & $\begin{array}{c}0.161 \\
(1.806)^{*} \\
\end{array}$ & $\begin{array}{c}0.180 \\
(2.285)^{*} \\
\end{array}$ \\
\hline $\begin{array}{l}\text { Customer } \\
\text { relationship }\end{array}$ & $\begin{array}{c}1.322 \\
(1.789)^{4}\end{array}$ & $\begin{array}{c}0.127 \\
(1.172)^{*}\end{array}$ & $\begin{array}{c}0.105 \\
(1.283)^{*}\end{array}$ & $\begin{array}{c}0.132 \\
(1.392)^{*}\end{array}$ & $\begin{array}{c}0.278 \\
(2.833)^{* *}\end{array}$ & $\begin{array}{c}0.110 \\
(1.393)^{*}\end{array}$ \\
\hline $\begin{array}{c}\text { Information } \\
\text { Sharing }\end{array}$ & $\begin{array}{c}1.924 \\
(4.543)^{* *}\end{array}$ & $\begin{array}{c}0.267 \\
(3.298)^{4 *}\end{array}$ & $\begin{array}{c}0.325 \\
(2.955)^{* *}\end{array}$ & $\begin{array}{c}0.163 \\
(2.095)^{\star}\end{array}$ & $\begin{array}{c}0.288 \\
(3.267)^{* *}\end{array}$ & $\begin{array}{c}0.163 \\
(2.065)^{*}\end{array}$ \\
\hline Adj R2 & 0.422 & 0.399 & 0.483 & 0.261 & 0.353 & 0.263 \\
\hline F-value & $14.453^{* * *}$ & $10.222^{* *}$ & $9.743^{* *}$ & $6.542^{* *}$ & $12.529 * *$ & $7.525^{* *}$ \\
\hline
\end{tabular}

${ }^{*}$ p value $<0.05,{ }^{* *}$ p value $<0.01$

The specifics of each hypothesis testing result can be summarized in Table 6

Table 6: Summary Result of Hypotheses Testing

\begin{tabular}{|c|l|l|}
\hline Hypotheses & & \multicolumn{1}{|c|}{ Description } \\
\hline $\mathrm{H} 1$ & Supply chain management practices are positively related to supply chain responsiveness & Accepted \\
\hline $\mathrm{H} 1 \mathrm{a}$ & Strategic supplier partnership is positively related to supply chain responsiveness & Accepted \\
\hline $\mathrm{H} 1 \mathrm{~b}$ & Customer relationship is positively related to supply chain responsiveness & Accepted \\
\hline $\mathrm{H} 1 \mathrm{c}$ & Information sharing is positively related to supply chain responsiveness & Accepted \\
\hline & & \\
\hline $\mathrm{H} 2$ & Supply chain management practices are positively related to competitive advantage & Accepted \\
\hline $\mathrm{H} 2 \mathrm{a}$ & Strategic supplier partnership is positively related to competitive advantage & Accepted \\
\hline $\mathrm{H} 2 \mathrm{~b}$ & Customer relationship is positively related to competitive advantage & Accepted \\
\hline $\mathrm{H} 2 \mathrm{c}$ & Information sharing is positively related to competitive advantage & Accepted \\
\hline
\end{tabular}

\section{Hypotheses Testing Results}

In this analysis, the accompanying results were acquired: The correlation analysis indicated that organizational change and supply chain management practices is term of strategic supplier organization, customer relationship and data sharing are identified with supply chain responsiveness in term of activity framework responsiveness, calculated procedure responsiveness and supplier arrange responsiveness. 
Organizational change and supply chain management practices likewise identified with upper hand of the firm in term of value, quality, delivery reliability, time to market and product development. For speculation 1a, this analysis found a huge correlation between strategic supplier organization and activity framework responsiveness, calculated procedure responsiveness and supplier arrange responsiveness. While hypothesis $1 \mathrm{~b}$ evaluated the correlation between customer relationship and activity framework responsiveness, strategic procedure responsiveness and supplier organize responsiveness, discovering appear there is huge relationship.

Hypothesis 1c, considered the correlation between data sharing and activity framework responsiveness, calculated procedure responsiveness and supplier organize responsiveness and testing found that there is a critical relationship. As indicated by the outcome demonstrated data sharing was the determinant impact of supply chain responsiveness, trailed by customer relationship and strategic supplier organization individually. The analyst found that data sharing has solid determinant on supply chain responsiveness than customer relationship and strategic supplier organization. Subsequently, the better data sharing, the better supply chain responsiveness was. From these findings, chief from SMEs division in Malaysia's ought to improve data sharing adequately, so supply chain responsiveness can be expanded and create the firm performance.

For hypothesis $2 \mathrm{a}$, this analysis found a noteworthy correlation between vital supplier organization and value, quality, delivery constancy, time to market and product advancement. While speculation $2 \mathrm{~b}$ surveyed the correlation between customer relationship and value, quality, delivery constancy, time to market and product advancement, discovering appear there is critical relationship. Speculation $2 c$, considered the correlation between data sharing value, quality, delivery steadfastness, time to market and product development and testing found that there is a noteworthy relationship. As per the outcome additionally demonstrated data sharing was the determinant impact of upper hand of the firm, trailed by customer relationship and vital supplier organization individually. The scientist found that data sharing has solid determinant on upper hand than customer relationship and strategic supplier organization. Subsequently, the better data sharing, the better upper hand was. In light of these findings, manager from SMEs part in Malaysia's ought to improve data sharing successfully, with the goal that supply chain upper hand can be expanded and create the firm performance.

\section{Discussion}

The point of the analysis introduced in this exploration was to include to the data organizational change and supply chain management practices by investigating the correlation between strategic supplier organization, customer relationship, data sharing and supply chain responsiveness. By creating and testing an analysis system of organizational change and supply chain management practices and supply chain responsiveness develops and leading an analysis various buyer products firm with legitimate and dependable instrument, this analysis spoke to one of the explore the correlation between vital supplier organization - supply chain responsiveness, customer relationship-supply chain responsiveness and data sharing - supply chain responsiveness. This analysis likewise explored the correlation between organizational change and supply chain management practices and upper hand of the firm.

Generally speaking, this analysis adds to the data on the job of organizational change and supply chain management practices, supply chain responsiveness and upper hand of the firm in organizational change and supply chain management field. Initially, it proposed a hypothetical organizational change and supply chain management practices system that distinguished strategic supplier organization, customer relationship and data sharing and upper hand of the firm. Second, this analysis gives a commonsense and valuable instrument for supply chain chief from SMEs area in Malaysia's to review and evaluate organizational change and supply chain management practices. Third, this analysis gives calculated and prescriptive literature with respect to organizational change and supply chain management practices, supply chain responsiveness and upper hand of the firm. Fourth, the outcomes loan backing to the case that better of organizational change and supply fasten management practices lead to better of supply chain responsiveness and upper hand of the firm. Administrator from SMEs segment in Malaysia looking for improved supply chain responsiveness and upper hand through organizational change and supply chain management practice. The findings of this analysis have a few significant ramifications for specialists.

In the first place, as the present business rivalry are moving from among SME organizations in Malaysia to between supply chains accomplices,

SME organizations in Malaysia are progressively receiving organizational change and supply chain management practices, in the expectation for creating supply chain responsiveness and upper hand of the firm. Analysis finding demonstrated that $47 \%$ of the respondents showed that their firm has not set out upon a program pointed uniquely at actualizing organizational change and supply chain management. 
Of the staying $53 \%$ of the respondents demonstrated that their firm has set out on anorganizational change and supply chain management program for only two years or less.

\section{Conclusion}

The findings of this exploration guarantee the experts that SCM is a compelling method of contending, and the usage of SCM practices strongly affects supply chain responsiveness and upper hand of the firm. Second, in the present relentless worldwide rivalry, SME organizations in Malaysia are needing more noteworthy responsiveness, in order to quickly address customer issues. Besides, responsiveness on all measurements, in particular, supply side, inside the organization, and downstream is required for absolute responsiveness of the firm. Supply chain responsiveness has been inadequately characterized and there is a serious extent of fluctuation (going from adaptability to readiness) in individuals' psyche about its significance. The findings show to the specialists the crucial segments of responsiveness, and methods of accomplishing them. Third, the analysis gives SME organizations in Malaysia a lot of legitimate and dependable estimations for assessing, benchmarking, and looking at supply chain responsiveness at various hubs inside the supply chain (instance crude material supplier, part supplier, constructing agent, sub-constructing agent, producer, merchant, distributer, and retailer). The estimations created in this exploration can catch the various parts of supply chain responsiveness, consequently not just empowering use by experts to distinguish its prompt results, yet in addition to comprehend its effects on organizational performance.

\section{References}

A.A. Thatte (2007), "Competitive advantage of a Firm Through Supply Chain Responsiveness and Supply Chain Management Practices", Published PhD Dissertation. University of Toledo.

Ashish A. Thatte. (2007), "Competitive Advantage of a Firm through Supply Chain Responsiveness and SCM Practices" Published, PhD Dissertation. The University of Toledo.

Ballou, R. H., Gilbert, S. M., \& Mukherjee, A. (2000). New managerial challenges from supply chain opportunities. Industrial Marketing Management, 29, 7-18.

Bommer, M., O'Neil, B. and Treat, S. (2001), "Strategic Assessment of the Supply Chain Interface: a Beverage Industry Case Study", International Journal of Physical Distribution and Logistics Management, 31(1), pp.1125.

Bowersox, D.J. and Closs, D.J. (1996), Logistical Management: The Integrated Supply Chain Process, McGraw-Hill.

Chen, I. J. and Paulraj, A. (2004), "Towards A Hypothesis of Supply Chain Management: The Constructs and Measurements", Journal of Operations Management, 22(2), pp. 119- 50.

Chen, I. J. and Paulraj, A. (2004), "Understanding Supply Chain Management: Critical Research and a Theoretical Framework", International Journal of Production Research, 42(1), pp. 131-163.

Christopher, M. (2000), “The Agile Supply Chain", Industrial Marketing Management, 29(1), pp. 37-44. Christopher, M. G. (1992), Logistics and Supply Chain Management, Pitman Publishing, London, UK.

Christopher, M. and Peck, H. (2004), "Building the Resilient Supply Chain", International Journal of Logistics Management, 15(2), pp. 1-13.

Clinton, S. R. and Closs, D. J. (1997), “Logistics Strategy: Does It Exist?”, Journal of Business Logistics, 18(1), pp. 19- 44.

Cooper, D. M. Lambert, and J. D. Pagh, (1997). "Supply chain management: more than a new name for logistics," The International Journal of Logistics Management, vol. 8, pp. 1-14.

Davenport, T. H., Harris, J. G., De Long, D. W., and Jacobson, A. L. (2001), "Data to Knowledge to Results: Building an Analytic Capability", California Management Review, 43(2), pp. 117-139.

Duclos, L. K.., Vokurka, R. J., and Lummus, R. R. (2003), "A Conceptual Model of Supply Chain Flexibility", Industrial Management \& Data Systems, 103(6), pp. 446-456.

Ellram, L. M. (1991), "Supply Chain Management: The Industrial Organization Perspective", International Journal of Physical Distribution and Logistics Management, 21(1), pp. 13-22.

Fawcett, S. E. (1992), "Strategic Logistics in Coordinated Global Manufacturing Success", International Journal of Production Research, 30(5), pp. 1081-2000.

Frohlich, M.T. and Westbrook, R. (2001), "Arcs of Integration: An International Study of Supply Chain Strategies", Journal of Operations Management, 19(2), pp. 185-200.

Giannocearo, L. And Pontrandolfo, P. (2002), "Inventory Management in Supply Chains: A Reinforcement Learning Approach”, International Journal of Production Economics, 78(2), pp.153-161

Goldman, S., Nagel, R., and Preiss, K. (1995), Agile Competitors and Virtual organisations: Strategies for Enriching the Customer, Van Nostrand Reinhold, New York, NY. 
Greene, A. H. (1991), "Supply Chain of Customer Satisfaction", Production and Inventory Management Review and APICS News, 11(4), pp. 24-25.

Gunasekaran, A., Patel, C., and Tirtiroglu, E. (2001), "Performance Measures and Metrics in a Supply Chain Environment", International Journal of Operations and Production Management, 21(1/2), pp. 71-87.

Lambert, D. M., Cooper, M. C., and Pagh, J. D. (1998), "Supply Chain Management: Implementation Issues and Research Opportunities," International Journal of Logistics Management, 9(2), pp. 1-20.

Lambert and M. C. Cooper. (2000)."Issues in supply chain management," Industrial Marketing Management, vol. 29, pp. 65-83.

Larson and D. S. Rogers, (1998)."Supply chain management: definition, growth and approaches," Journal of Marketing Hypothesis and Practice, vol. 6, pp. 1-5.

Lee, H. L. (2004), “The Triple-A Supply Chain”, Harvard Business Review, 82(10), pp. 102-112.

Li, S., Rao, S. Subba, Ragu-Nathan, T. S., and Ragu-Nathan, B. (2005), "Development and Validation of A Measurement Instrument for Studying Supply Chain Management Practices", Journal of Operations Management, 23(6), pp. 618-641.

Li, S., Ragu-Nathan, B., Ragu-Nathan, T. S., and Rao, S. Subba (2006), "The Impact of Supply Chain Management Practices on Competitive Advantage and Organizational Performance", Omega, 34(2), pp. 107-124.

Lummus, R. R. and. Vokurka, R. J. (1999), "Defining Supply Chain Management: A Historical Perspective and Practical Guidelines", Industrial Management \& Data Systems, 99(1), pp. 11-17.

Lummus, R. R., Duclos, L. K., and Vokurka, R. J. (2003), "Supply Chain Flexibility: Building a New Model”, Global Journal of Flexible Systems Management, 4(4), pp. 1-13.

Min, S. and Mentzer, J. T. (2004), "Developing and Measuring Supply Chain Concepts”, Journal of Business Logistics, 25(1), pp. 63-99.

Magretta, J. (1998), “The Power of Virtual Integration: An Interview with Dell Computers' Michael Dell”, Harvard Business Review, 76(2), pp.72-84.

M.J. Braunscheidel (2005), "Antecedents of Supply Chain Agility: An Empirical Analysis”, Published Dissertation, Faculty of the Graduate School of The State University of New York at Buffalo.

Moberg, C. R., Cutler, B. D., Gross, A., and Speh, T. W. (2002), "Identifying Antecedents of Data Exchange Within Supply Chains", International Journal of Physical Distribution and Logistics Management, 32(9), pp. 755-770.

Nunnally, J. C. (1978).Psychometric Hypothesis. McGraw-Hill, New York, NY.

Ricker, F. and Kalakota, R. (1999), "Order Fulfillment: The Hidden Strategic to E-Commerce Success", Supply Chain Management Review, 11(3), pp. 60-70.

Scott, C. and Westbrook, R. (1991), "New Strategic Tools for Supply Chain Management", International Journal of Physical Distribution and Logistics, 21(1), pp. 23- 33.

Simatupang, T. M. and Sridharan, R. (2002), “The Collaborative Supply Chain”, International Journal of Logistics Management, 13(1), pp. 15-30.

Simatupang, T. M. and Sridharan, R. (2005), "An Integrative Framework for Supply Chain Collaboration", International Journal of Logistics Management, 16(2), pp. 257- 274.

Tage, S. (1999). Supply chain management: A new challenge for researchers and managers in logistics. International Journal of Logistics Management, 10(2), 41-53.

Tan, K. C., Lyman, S. B., and Wisner, J. D. (2002), "Supply Chain Management: A Strategic Perspective", International Journal of Operations and Production Management, 22(6), pp. 614-631.

Towill, D. and Christopher, M. (2002), "The Supply Chain Strategy Conundrum: To be Lean Or Agile or To be Lean And Agile?", International Journal of Logistics: Research \& Applications, 5(3), pp. 299-309.

Turner, J. R. (1993), "Integrated Supply Chain Management: What's Wrong With This Picture?", Industrial Engineering, 25(12), pp. 52-55.

Wines, L. (1996), "High Order Strategy for Manufacturing", The Journal of Business Strategy, 17(4), pp. 32-33.

Yoshino, M. and Rangan, S. (1995), "Strategic Alliances: An Entrepreneurial Approach To Globalization", Harvard Business School Press, Boston, MA. 